\title{
E KREASI LAGU ANAK BERBAHASA INGGRIS (NURSERY RHYMES) SEBAGAI MEDIA UNTUK MENGENALKAN BAHASA INGGRIS PADA ANAK USIA DINI
}

\section{Sri Wahyuningsih}

Institut Agama Islam Negeri Kudus, Kudus, Indonesia

wahyuningsih@iainkudus.ac.id

\begin{abstract}
This article mainly explores the importance of improving English language skills in early childhood through the creation and modification of English-language children's songs (nursery rhymes) and obstaclesinlearning. Thisstudy used a qualitative method with an approach of descriptive analysis. In collecting data, the author used a field research in the form of interviews, observation and documentation. The result reveals that the creation of children's songs in English is very useful as a medium for introducing English in early childhood including Playgroups and Kindergarten in Kudus. By singing children's songs in English, children feel more interested in learning English. Further, they feel more relaxed since they learn English vocabulary while singing. Besides, they don't feel stressed during the learning process. In addition, by singing nursery rhymes, children development can be maximally stimulated including physical, social, emotional, and intellectual abilities. The obstacles found in learning process include the limited attention and concentration of the children towards the teacher, the limited insight and knowledge of the teachers in playgroups and Kindergartens about teaching English, and the limited means of support and facilities in learning English.
\end{abstract}

Keywords: Early Childhood English; Children's Songs; Nursery Rhymes.

\begin{abstract}
Abstrak: Artikel ini membahas tentang pentingnya meningkatkan kemampuan berbahasa Inggris anak usia dini melalui kreasi dan modifikasi lagu-lagu anak berbahasa Inggris (nursery ryhmes) dan kendala dalam pembelajaran. Penelitian ini menggunakan metode kualitatif dengan pendekatan pada analisis deskriptif. Untuk mengumpulkan data, penulis menggunakan penelitian lapangan berupa wawancara, observasi dan dokumentasi.Hasil menunjukkan bahwa kreasi lagu-lagu anak berbahasa Inggris sangat berguna sebagai media untuk mengenalkan bahasa Inggris pada anak-anak usia dini di Kelompok Bermain (KB) dan Taman Kanak-Kanak (TK) di Kudus. Dengan menyanyikan lagu-lagu anak berbahasa Inggris, anak-anak merasa lebih tertarik dan semangat dalam belajar bahasa Inggris. Mereka merasa lebih santai karena belajar kosa kata bahasa Inggris sambil bernyanyi, mereka tidak merasa tertekan (stress) pada saat pembelajaran di kelas. Melalui bernyanyi, perkembangan anak dapat terstimulasi dengan maksimal seperti fisik-motorik, sosial, emosional, dan intelektual. Adapun kendala-kendala selama pembelajaran meliputi terbatasnya daya perhatian dan konsentrasi anak terhadap guru ketika mengajar bahasa Inggris, terbatasnya wawasan dan pengetahuan yang luas dari guru-guru di KB dan TK tentang pengajaran bahasa Inggris, terbatasnya sarana penunjang dan fasilitas dalam pembelajaran bahasa Inggris.
\end{abstract}

Kata kunci: Anak Usia Dini; Bahasa Inggris; Lagu Anak; Nursery Rhymes. 


\section{A. Pendahuluan}

Di era milenial, menguasai bahasa Inggris merupakan sebuah tuntutan dalam mengikuti perkembangan zaman. Bahasa Inggris dianggap sebagai bahasa asing di beberapa negara termasuk Indonesia. Oleh karenanya, bahasa Inggris perlu diajarkan kepada siswa di beberapa sekolah. Di Indonesia, pengajaran bahasa Inggris mulai diwajibkan di sekolah menengah pertama (SMP). Meskipun demikian, penguasaan bahasa Inggris para siswa dirasa belum maksimal terutama pada aspek berbicara bahasa Inggris karena penekanan materi bahasa Inggris yang diajarkan lebih fokus pada tata cara bahasa (grammar). Selain itu, para siswa juga tidak didukung dengan lingkungan atau atmosfir bahasa Inggris sehingga mereka jarang mendengar dan menggunakan bahasa Inggris. Hal ini senada dengan pendapat Ghanbari \& Hashemian (2014) yang mengungkapkan bahwa siswa dirasa kurang maksimal dalam belajar bahasa Inggris karena mereka jarang mendengar orang-orang di sekitarnya berbicara bahasa inggris. Oleh karenanya, guru bahasa Inggris hendaknya memiliki tanggung jawab untuk membantu siswa terutama meningkatkan kemampuan mendengar bahasa Inggris (listening) lebih baik lagi. Siswa akan mampu berbicara bahasa Inggris lebih baik jika kemampuan mendengar (listening) maksimal.

Permasalahan di atas menunjukkan bahwa bahasa Inggris dirasa penting untuk diperkenalkan kepada anak sejak usia dini seperti di PAUD dan taman kanak-kanak sebab di usia tersebut anak berada pada usia emas (golden age) sehingga lebih mudah menerima materi (input). Sebagaimana diungkapkan oleh Lonigan, Burgess, \& Anthony (2000) bahwa anak-anak usia dini diharapkan memiliki kemampuan dalam pengucapan bahasa yang tepat termasuk bahasa Inggris. Hal ini dikarenakan bahwa penguasaan dan kesadaran akan kemampuan mendengar dan berbicara menjadi landasan untuk meningkatkan kemampuan membaca (Harper, 2011, hal. 65). Ada beberapa cara untuk memperkenalkan bahasa Inggris kepada anak usia dini salah satunya melalui nursery rhymes atau lagu anak berbahasa Inggris.

Beberapa studi tentang pembelajaran bahasa Inggris pada anak usia dini telah dilakukan oleh para peneliti. Brodin \& Renblad (2019, hal. 1) telah mengembangkan kemampuan komunikasi dan bahasa anak melalui membaca keras (reading aloud) dan bercerita (story telling). Urgensi memperkenalkan bahasa Inggris pada anak sejak usia dini yaitu pendidikan anak usia dini seperti PAUD dan taman kanak-kanak (TK) memiliki peran utama dan sebagai dasar dalam pengembangan bahasa. Hery, Nair, \& Krishnasamy (2016, hal. 2) dalam penelitiaannya telah berhasil mengoptimalkan minat siswa dalam belajar bahasa Inggris di Sekolah Dasar (SD) melalui nursery rhmes. Dalam hal ini, para siswa 
lebih aktif dalam mengikuti proses belajar mengajar dan mereka terlihat percaya diri ketika belajar bahasa Inggris. Selanjutnya, Prosic-santovac (2015, hal. 25) mengembangkan kriteria dalam penggunaan lagu anak berbahasa Inggris dalam proses pembelajaran meliputi isi, ilustrasi dan bahasa. Pourkalhor \& Tavakoli (2017, hal. 111) menjelaskan bahwa peran lagu anak (nursery rhymes) sangat penting dalam proses pembelajaran bahasa karena dapat membantu guru dalam memotivasi siswa belajar bahasa Inggris sehingga mereka lebih terdorong untuk berinteraksi sambil mendengarkan lagu. Lebih lanjut, Mustafa \& Ahmad (2017, hal. 13) mendeskripsikan tentang strategi interaksi menggunakan bahasa Inggris selama proses pembelajaran oleh guru-guru taman kanak-kanak (TK) di Kerian, Perak. Secara lebih detail, Klein \& Knitzer (2006, hal. 2) lebih menekankan pada pentingnya strategi-strategi yang digunakan untuk mendukung kompetensi sosial dan emosional anak-anak usia dini sebagai dasar untuk belajar yang lebih aktif. Oleh karena itu, guru yang mengajar bahasa Inggris dituntut untuk menggunakan metode, strategi, teknik dan sebagainya. Dalam hal ini, guru memiliki peran penting dalam menransfer ilmu, memfasilitasi siswa ketika belajar, dan mengevaluasi kebutuhan dan standar kualifikasi pembelajaran (Liakopoulou, 2011, hal. 66).

Berbeda dengan penelitian-penelitian sebelumnya yang menjelaskan secara umum peran lagu anak (nursery rhymes) dalam mengajar bahasa Inggris, artikel ini lebih fokus pada menciptakan lagu anak berbahasa Inggris (nursery rhymes) sebagai media untuk memperkenalkan bahasa Inggris kepada anak-anak usia dini di Kudus. Dalam hal ini, para mahasiswi program studi PIAUD IAIN Kudus yang ikut mengajar di PAUD dan TK dapat mengganti lirik lagu, isi dan makna lagu sesuai dengan budaya, tema dan kehidupan sehari-hari sehingga lebih mudah didengarkan, diucapkan dan dipahami maknanya oleh anak usia dini. Lebih lanjut, artikel ini juga membahas tentang contoh-contoh kreasi lagu anak berbahasa Inggris yang telah dimodifikasi oleh guru-guru dan implementasinya di kelas serta hambatan atau tantangan dalam memperkenalkan bahasa Inggris pada anak-anak menggunakan nursery rhymes.

Penelitian ini menggunakan metode penelitian kualitatif dengan pendekatan pada analisis deskriptif yang bertujuan untuk menggambarkan tentang pentingnya kreasi nursery rhymes yang disesuaikan dengan kebutuhan, budaya, nilai-nilai kehidupan untuk memperkenalkan bahasa Inggris pada anak usia dini di Kudus, contoh-contoh kreasi nursery rhymes, dan kendala dalam memperkenalkan bahasa Inggris pada anak usia dini. Untuk mengumpulkan data, penulis menggunakan penelitian lapangan berupa wawancara mendalam (indepth interview) kepada para mahasiswi Program Studi PIAUD IAIN Kudus yang praktik mengajar di satuan pendidikan anak usia dini yaitu Kelompok Bermain (KB) dan Taman Kanak-Kanak (TK) di Kudus yang meliputi KB Taman Melati, 
KB As-Shidiqiyyah, KB Ustman bin Affan, TK Rahmatul Ummah, TK Pertiwi, TK IT Rohmatul Ulum. Selain itu, observasi dan dokumentasi juga dilakukan untuk mendapatkan data lebih lanjut. Setelah data terkumpul, maka dilakukan analisis data dengan menggunakan metode analisis data kualitatif model interaktif yang meliputi: pengumpulan data, reduksi data, penyajian data, dan penarikan kesimpulan.

\section{B. Pembahasan}

\section{Kreasi Nursery Rhymes oleh Mahasiswi PIAUD di IAIN Kudus Untuk Meningkatkan Kemampuan Bahasa Inggris Anak usia Dini}

Anak-anak di usia dini cenderung mengalami kendala dalam pengucapan bahasa Brodin \& Renblad (2019, hal. 1). Hal ini termasuk dalam pengenalan dan pengajaran bahasa Inggris sebagai bahasa asing. Mengingat peran bahasa Inggris digunakan di berbagai negara yakni sebagai bahasa Internasional, maka semua orang diharapkan memiliki kemampuan berbahasa Inggris dengan baik. Di Indonesia, pengajaran bahasa Inggris mulai wajib diajarkan pada tingkat sekolah menengah pertama (SMP). Hal ini menjadikan penguasaan bahasa Inggris para siswa dirasa belum maksimal terutama pada aspek berbicara bahasa Inggris karena penekanan materi bahasa Inggris yang diajarkan lebih fokus pada tata cara bahasa (grammar). Lebih dari itu, para siswa juga tidak didukung dengan lingkungan atau atmosfir bahasa Inggris sehingga mereka jarang mendengar dan menggunakan bahasa Inggris. Meskipun demikian, ada beberapa sekolah tertentu di Indonesia terutama sekolah elit di kota-kota besar seperti Jakarta, Semarang dan Surabaya yang mulai memperkenalkan bahasa Inggris pada siswanya di tingkat taman kanak-kanak dan sekolah dasar (SD). Hal ini diharapkan siswa memiliki dasar pengetahuan bahasa Inggris sejak awal sehingga lebih mudah dikembangkan di level atau sekolah berikutnya.

Berbeda dengan sekolah-sekolah di kota-kota besaryang sudah mengenalkan atau mengajarkan bahasa Inggris sejak dini misalnya kelompok bermain dan taman kanak-kanak, beberapa kelompok bermain (KB) dan Taman Kanak-Kanak (TK) di kota-kota kecil seperti Kudus, Jawa Tengah dirasa belum maksimal dalam mengenalkan atau mengajarkan bahasa Inggris bahkan ada beberapa KB atau TK di pedesaan yang belum mengenalkan bahasa Inggris pada siswanya. Hal ini disebabkan oleh terbatasnya kemampuan guru dalam menguasai bahasa Inggris, kurangnya strategi dan metode dalam memperkenalkan bahasa Inggris, dan lingkungan serta sarana yang kurang mendukung. Oleh karena itu, guru-guru diharapkan memiliki cara, strategi dan metode yang menarik ketika mengajar bahasa Inggris pada anak usia dini. 
Salah satu cara mengajarkan bahasa Inggris kepada anak usia dini dapat menggunakan lagu anak berbahasa Inggris (nursery rhymes). Akan tetapi, tidak semua lagu-lagu anak berbahasa Inggris mudah dinyanyikan dan diajarkan kepada anak usia dini di KB dan TK di Kudus mengingat kosa kata dan pengucapan bahasa Ingris tidak mudah bagi anak-anak. Oleh karena itu, lagu-lagu termasuk perlu dimodifikasi dengan cara mengubah lirik lagu dan disesuaikan dengan kondisi dan lingkungan anak agar mudah diterima oleh mereka. Dengan menciptakan dan memodifikasi lagu bahasa Inggris (nursery rhymes), guru-guru dapat mengajarkan bahasa Inggris lebih mudah pada anak melaui bernyanyi bersamasama. Hal ini dikarenakan musik secara alamiah memberikan kesempatan pola praktik, konsep-konsep matematika, dan kemampuan berpikir simbolik serta dapat memberikan hiburan dan berfungsi sebagai cara untuk meredakan ketegangan dan kebosanan (Wahyuningsih, 2017, hal. 172).

Ada beberapa lagu anak berbahasa Inggris (nursery rhymes) yang diciptakan atau dimodifikasi oleh beberapa para mahasiswi prodi PIAUD IAIN Kudus yang mengajar di Kelompok Bermain (KB) dan Taman Kanak-Kanak (TK) di Kudus untuk dijadikan media dalam mengenalkan bahasa Inggris pada anak-anak. Lagu-lagu tersebut diantaranya:

\section{a. Judul "One, Two and Three" (Satu, dua, tiga)}

One and one, I love my father

Two and two, I love my father

Three and three, I love brother and sister

One, two, and three, I love my family

Lagu di atas merupakan lagu yang dimodifikasi dari lagu anak Indonesia dengan judul asli "satu, dua, tiga". Lagu tersebut sangat populer di kalangan anak-anak Indonesia sejak dahulu hingga sekarang. Oleh karenanya, guru-guru memodifikasi lagu tersebut dengan mengganti lirik berbahasa Inggris "One, Two, and Three". Adapun nilai dan makna yang terkandung pada lagu "one, two, and three" adalah mengenalkan kepada anak tentang anggota keluarga meliputi ayah, ibu, kakak, adik dan pesan moral untuk menyayangi keluarga. Selain itu, kreasi lagu anak dengan judul "one, two, and three" sangat mudah ditirukan oleh anak-anak karena liriknya sederhana dan mudah dihafalkan. Selain itu, anak-anak juga sudah familiar dengan nada lagu tersebut.

Lagu ini telah digunakan oleh guru-guru di Kelompok Bermain (KB) dan Taman Kanak-Kanak (TK) di kelas untuk mengenalkan bahasa Inggris pada anak. Sebagai contoh di TK Nurul Jannah, guru-guru mengenalkan bahasa Inggris dengan cara menyanyikan lagu kreasi (nursery rhymes) dengan judul 
"one, two and three" bersama anak-anak. Untuk lebih menarik perhatian anakanak, para guru biasanya bernyanyi bersama mereka dengan menggunakan gerakan tubuh (gestures) secara berulang-ulang sampai anak mulai hafal lagu.

\title{
b. Judul "Yellow Kuning" (Are You Sleeping)
}

\author{
Yellow Kuning $2 x$ \\ Red Merah $2 x$ \\ Blue biru \\ Green Hijau \\ Blue biru \\ Green Hijau \\ White putih \\ Black hitam
}

Lagu di atas merupakan modifikasi dari lagu bahasa Inggris yang berjudul "Are you sleeping" yang diganti liriknya. Tujuan dari modifikasi tersebut adalah untuk mengenalkan macam-macam warna pada anak menggunakan bahasa Inggris. Selain itu, liriknya sangat sederhana dan mudah dinyanyikan oleh anak-anak. Lagu tentang warna ini telah digunakan oleh guru-guru Kelompok Bermain (KB) dan Taman Kanak-Kanak (TK) di kudus.

\section{c. Judul "Cha Ca Marica He He"}

\author{
One angka 1 \\ Two angka 2 \\ Three angka 3 \\ Four angka 4 \\ Cha ca marica hehe $2 x$ \\ Ayo berhitung pakai bahasa Inggris \\ Five angka 5 \\ Six angka 6 \\ Seven angka 7 \\ Eight angka 8 \\ Nine angka 9 \\ Ten angka 10 \\ Cha ca marica hehe $2 x$ \\ Ayo berhitung pakai bahasa Inggris
}

Lagu "cha ca marica he he" merupakan salah satu lagu yang dinyanyikan oleh anak-anak pramuka dan cukup populer di Indonesia. Liriknya yang sederhana, bernuansa ceria dan semangat membuat anak-anak senang menyanyikan lagu tersebut. Oleh karena itu, mahasiswi jurusan PIAUD di IAIN Kudus yang ikut mengajar di kelompok bermain dan taman kanak-kanak di Kudus memiliki inisiatif mengganti lirik lagu "cha ca marica he he" dengan 
lirik tentang angka menggunakan bahasa Inggris. Kemudian kreasi lagu ini dinyanyikan bersama anak-anak di kelas untuk mengenalkan angka-angka menggunakan bahasa Inggris.

\title{
d. Judul "Lion singa" (Are you sleeping)
}

\author{
Lion singa $2 x$ \\ Cat kucing $2 x$ \\ Elephant gajah $2 x$ \\ Mouse tikus $2 x$
}

Lagu "Lion Singa" merupakan modifikasi dari lagu anak bahasa Inggris (nursery rhymes) dengan judul "Are You Sleeping”. Tujuan modifikasi lagu ini adalah untuk mengenalkan nama-nama binatang mamalia menggunakan bahasa Inggris pada anak meskipun tidak semua jenis binatang disebutkan dalam lagu tersebut. Lagu ini dapat dinyanyikan oleh guru-guru dan anak-anak dengan mudah di kelas.

\section{e. Judul "Selamat pagi- Good morning" (Ada Kodok Rekotok Rekotok)}

\author{
Selamat pagi - good morning $2 x$ \\ Apa kabar-how are you $2 x$ \\ Saya senang-I'm happy $2 x$ \\ Setiap hari- every day $2 x$
}

Lagu "selamat pagi-good morning" merupakan modifikasi dari lagu anak dengan judul "ada kodok rekotok rekotok". Irama lagu tersebut sangat menarik dan menyenangkan bagi anak-anak Indonesia. Oleh karenanya, lirik lagu dapat diganti dan disisipi bahasa Inggris. Tujuan kreasi lagu anak bahasa Inggris dengan cara modikasi ini adalah untuk mengenalkan kepada anak-anak tentang cara menyapa dan menjawab sapaan orang lain. Selain itu, liriknya sangat sederhana dan mudah dihafalkan oleh anak-anak.

\section{f. Judul "Happy Holiday" (Baby Shark)}

Happy holiday na na na na na na Happy holiday na na na na na na Happy holiday na na na na na na Holiday 
We can play na na na na na na We can play na na na na na na We can play na na na na na na We can play

Don't be shy na na na na na na Don't be shy na na na na na na Don't be shy na na na na na na Don't be shy

Turn around na na na na na na Turn around na na na na na na Turn around na na na na na na Turn around

Be happy na na na na na na Be happy na na na na na na Be happy na na na na na na Be happy

Lagu "Happy Holiday" merupakan kreasi lagu anak dengan memodifikasi lagu bahasa Inggris dengan judul “ baby shark”. Lagu "baby shark” sangat terkenal dan dinyanyikan oleh anak-anak di Indonesia lewat media sosial (youtube). Iramanya yang unik disertai pengulangan di akhir liriknya membuat para mahasiswi jurusan PIAUD di IAIN Kudus sekaligus praktik mengajar di KB dan TK di Kudus mengganti lirik lagu tersebut untuk mengenalkan kepada anak-anak tentang aktivitas liburan (holiday).

\section{g. Judul "Thumb Finger-thumb finger where are you" (Mommy Finger-Mommy Finger where are you)}

Thumb Finger-thumb finger where are you Here I am, here I am, how do you do

Fore finger-fore finger where are you Here I am, here I am, how do you do

Middle finger-middle finger where are you Here I am, here I am, how do you do

Ring finger-ring finger where are you Here I am, here I am, how do you do

Little finger-little finger where are you Here I am, here I am, how do you do 
Lagu 'thumb finger-thumb finger where are you' merupakan sebuah kreasi lagu anak dengan cara memodifikasi dan mengganti lirik dari lagu yang berjudul 'mommy finger-mommy finger where are you'. Tujuan kreasi lagu ini adalah untuk mengenalkan pada anak usia dini tentang macam-macam jari menggunakan bahasa Inggris misalnya: jari jempol (thumb), jari telunjuk (fore finger), jari tengah (middle finger), jari manis (ring finger), dan jari kecil (little finger). Lagu ini sangat asyik untuk dinyanyikan bersama anak-anak. Guru-guru dapat menyanyi sambil menunjukkan jari-jari bersama anak-anak. Dengan demikian, anak-anak dapat dengan mudah menghafal nama-nama jari menggunakan bahasa Inggris karena mereka belajar sambil bernyanyi lewat lagu. Selain itu, keterampilan motorik dan kognitif anak juga dapat berkembang melalaui lagu. Hal ini sesuai dengan pernyataan Parlakian, Rebecca, \& Lerner (2010, hal. 14) bahwa musik dan lagu terutama lagu anak memiliki manfaat luar biasa bagi perkembangan anak dan pendidikan karakter yang tidak hanya keterampilan sosial-emosional, tetapi juga keterampilan motorik dan kognitif anak.

Beberapa kreasi lagu-lagu anak (nursery ryhmes) di atas dapat memberi manfaat bagi anak-anak yang meliputi penanaman nilai, moral dan karakter, perkembangan sosial-emosional, perkembangan kognitif dan motorik anak. lebih lanjut, lagu-lagu anak dapat memberikan rangsangan kepada anakanak agar gembira karena pada dasarnya musik dan lagu merupakan aspek prnting bagi pendidikan anak usia dini (PAUD). Hal ini diperkuat oleh Taylor (2012, hal. 38) bahwa anak-anak merasa gembira dan bebas bergerak ketika mendengar musik dan mereka senang dengan aktivitas fisik yang bermanfaat bagi perkembangan kesehatan.

Berkaitan dengan pengenalan bahasa Inggris pada anak usia dini, kreasi lagu-lagu bahasa Inggris di atas dapat dijadikan sebagai media dalam menarik minat anak ketika belajar bahasa Inggris yang meliputi kosa kata (vocabulary), pengucapan (pronunciation), dan pendengaran (listening). Dengan kata lain, anak-anak yang sering mendengar dan menyanyikan lagu-lagu anak berbahasa Inggris akan lebih kaya kosa katanya dan mampu mengucapkan kosa kata dalam bahasa Inggris dibanding anak-anak yang jarang sekali mendengar dan menyanyikan lagu-lagu anak berbahasa Inggris. Hal ini sesuai dengan pernyataan salah satu mahasiswi jurusan Pendidikan Islam Anak Usia Dini (PIAUD) IAIN Kudus yang ikut mengajar di TK Nurul Jannah Jekulo Kudus:

"Mengajar anak-anak di KB dan TK tidaklah mudah. Guru harus memiliki strategi dan metode mengajar yang menarik agar anak-anak antusias dalam belajar khususnya mengajarkan atau mengenalkan bahasa Inggris pada anak. dalam hal ini, kreasi lagu anak berbahasa 
Inggris dapat dijadikan sebagai salah satu solusi dan cara mengenalkan bahasa Inggris pada anak-anak. Guru dapat memodifikasi lagu asli dengan mengganti lirik dan disesuaikan dengan budaya, kondisi lingkungan anak, tujuan atau pesan yang ingin disampaikan oleh guru. Lagu-lagu di atas merupakan kreasi dari saya dan teman-teman di jurusan PIAUD IAIN Kudus. lagu-lagu tersebut sangat efektif karena anak-anak dapat belajar sambil bernyanyi. Anak akan mengenal kosa kata bahasa Inggris, menyebutkan kosa kata berkaitan tentang warna, nama keluarga, nama binatang dan sebagainya". (wawancara dengan Muna, November 2018).

Hal ini senada dengan pernyataan Anifah, mahasiswi jurusan PIAUD di IAIN Kudus, yang ikut mengajar di Kelompok Bermain Taman Melati, Gebog, Kudus:

"Bernyanyi dapat dijadikan sebagai metode untuk mengenalkan bahasa Inggris pada anak usia dini. Dalam hal ini, guru sebagai pendamping peserta didik harus kreatif dalam memberikan pengajaran karena mengajarkan suatu hal baru kepada anak usia dini lebih mudah diserap pada usia emas (golden age). Ketika saya mengajarkan mereka tentang hewan, saya menggunakan lagu anak yang sudah saya modifikasi menggunakan bahasa Inggris. Anak-anak dapat bernyanyi dan belajar tentang nama-nama hewan menggunakan bahasa Inggris". (wawancara dengan Anifah, November 2018).

Dengan demikian, menyanyikan lagu anak memiliki nilai positif dan efektif dalam mengenalkan bahasa Inggris pada anak. Hal ini diperkuat dengan pernyataan Nikmah, mahasiswi jurusan PIAUD di IAIN Kudus.

"Keuntungan mengajarkan bahasa Inggris menggunakan kreasi lagu anak antara lain: melalui lagu anak, anak-anak merasa termotivasi ketika belajar bahasa Inggris. Dengan menyanyi, anak menjadi senang dan lebih mudah dalam memahami materi yang disampaikan guru. Melalui nyanyian bahasa Inggris dan kegiatan pembelajaran yang bervariasi, guru dapat menumbuhkan minat anak agar lebih senang dan giat belajar. Keterampilan motorik anak juga berkembang karena ketika bernyanyi mereka merasa bebas bergerak dan tanpa tekanan". (wawancara dengan Nikmah, November 2018).

Dari hasil wawancara dengan mahasiswi-mahasiswi yang mengajar di Kelompok Bermain dan taman kanak-kanak Kudus di atas dapat dilihat bahwa mengajarkan bahasa Inggris pada anak usia dini tidak mudah dan membutuhkan strategi, metode dan kreativitas untuk menarik minat anak dalam belajar. Dalam hal ini, kreasi dan modifikasi lagu anak bahasa Inggris dapat dijadikan sebagai metode untuk mengajarkan bahasa Inggris pada anak-anak Kelompok Bermain (KB) dan Taman Kanak-Kanak (TK). Dengan menyanyikan lagu-lagu 
anak bahasa Inggris, anak-anak merasa lebih santai karena belajar kosa kata bahasa Inggris sambil bernyanyi. Anak tidak merasa tertekan (stress) pada saat pembelajaran di kelas. Selain itu, guru juga bisa melaksanakan pembelajaran bahasa Inggris di luar kelar (out door) terutama pada tema tentang alam. Selain itu, dengan kondisi belajar senang dan riang anak usia dini menjadi semakin bergairah. Melalui bernyanyi, perkembangan anak dapat terstimulasi dengan maksimal seperti fisik-motorik, sosial, emosional, dan intelektual. Dengan kata lain, bernyanyi merupakan kegiatan yang tidak dapat dipisahkan dari kehidupan anak usia dini.

\section{Kendala Dalam Mengenalkan Bahasa Inggris pada Anak Usia Dini di KB dan TK}

Dalam mengenalkan bahasa Inggris pada anak usia dini, guru sebaiknya menggunakan strategi dan metode yang dapat membuat anak termotivasi dan semangat dalam belajar. Salah satunya dengan menggunakan kreasi lagu anak berbahasa Inggris. Meskipun demikian, ada beberapa kendala dalam mengajarkan bahasa Inggris pada anak usia dini. Kendala-kendala tersebut antara lain:

\section{a. Terbatasnya daya perhatian dan konsentrasi anak terhadap guru ketika mengajar bahasa Inggris.}

Anak-anak usia dini tidak bisa dipisahkan dari kegiatan bermain. Pada usia tersebut, anak-anak menunjukkan keaktifannya dalam berbagai hal. Misalnya ketika pembelajaran di kelas, sebagian besar anak masih terlihat asyik bermain, bercanda, dan mengobrol dengan teman-temannya sehingga daya perhatian dan konsentrasi mereka terhadap guru ketika mengajar bahasa Inggris menjadi tidak maksimal. Oleh karena itu, guru-guru dituntut untuk mampu menguasai kondisi kelas terlebih dahulu sebelum memulai pembelajaran bahasa Inggris. Lebih dari itu, guru juga harus mengenali karakteristik belajar pada anak-anak usia dini agar pembelajaran di kelas dapat berlangsung secara kondusif. Hal ini sejalan dengan O' Connell (2009, hal. 5) bahwa guru-guru yang mengajar di PAUD harus mampu mengetahui karakteristik bagaimana anak belajar, mampu mengembangkan konteks pembelajaran, dan mampu menyadari bahwa anak-anak merupakan pembelajar aktif yang memerlukan pengetahuan dan pengalaman dari dunia luar. Terbatasnya tingkat konsentrasi anak-anak ketika pembelajaran di kelas diungkapkan oleh mahasiswi jurusan PIAUD IAIN Kudus yang ikut mengajar di Kelompok Bermain (KB) Taman Melati, Kudus:

"Mengajar anak-anak usia dini di Kelompok Bermain dan Taman Kanak-Kanak sangat memerlukan ketelitian dan kesabaran. Ketika saya mengajarkan bahasa Inggris di Kb Taman Melati Kudus, kendala 
yang saya hadapi adalah anak-anak masih sibuk bermain dan bercanda dengan teman-temannya sehingga saya harus mengatur strategi dan meguasai kelas terlebih dahulu sebelum masuk ke topik pembelajaran”. (Näimah, November 2018).

\section{b. Beberapa anak masih menunjukkan rasa malu dan pasif ketika belajar bahasa Inggris.}

Bahasa Inggris bagi anak-anak Indonesia terutama di kudus merupakan bahasa asing sehingga mereka butuh waktu dan adaptasi untuk mengenal bahasa Inggris. Oleh karenanya, ketika anak-anak diajar bahasa Inggris oleh gurunya mereka belum maksimal dalam mengikuti pembelajaran. Hal ini terlihat ketika guru mengajak menyanyi bahasa Inggris, sebagian anak masih terlihat pasif dan diam. Sebagaimana pernyataan dari salah satu mahasiswa jurusan PIAUD IAIN Kudus, Wulandari, yang ikut mengajar di TK Pertiwi Kudus :

"Sebagian besar anak-anak paud awalnya masih menunjukkan rasa malu dan pasif ketika mereka diajak menyanyi lagu bahasa Inggris. Hal ini dikarenakan mereka masih beradaptasi dan belum familiar dengan lagu-lagu anak berbahasa Inggris. Anak-anak mulai terlihat mulai ikut bernyanyi setelah guru menyanyikan lagu tersebut beberapa kali. Dalam hal ini, para guru yang mengajar di KB dan TK hendaknya memiliki sifat sabar dalam mengajar dan terus mengasah kreativitas dalam mengajar agar anak merasa tertarik dan aktif dalam proses pembelajaran". (wawancara dengan Wulandari, November, 2018).

\section{c. Terbatasnya wawasan dan pengetahuan yang luas dari guru-guru di KB dan TK tentang pengajaran bahasa Inggris.}

Kurangnya wawasan, pengetahuan dan strategi tentang pengajaran bahasa Inggris pada anak-anak usia dini dari para guru menjadi kendala dalam proses pembelajaran. salah satu faktor penyebabnya adalah latar belakang (background) pendidikan para guru tidak jurusan pendidikan bahasa Inggris sehingga mereka merasa kesulitan dalam menciptakan suasana yang menyenangkan dalam mengajar bahasa Inggris, kurang menguasai strategi pengajaran bahasa Inggris bagi anak-anak usia dini, dan kurang menguasai metode pembelajaran bahasa Inggris bagi anak usia dini. Hal ini sesuai dengan hasil observasi di sekolah KB dan TK bahwa guru yang mengajar bahas Inggris berasal dari latar belakang (background) pendidikan anak usia dini (non-bahasa Inggris). Sebagaimana yang diungkapkan oleh Azizah, mahasiswi jurusan PIAUD yang melakukan praktik mengajar di Kelompok Bermain 'Ustman bin Affan' Kudus berikut: 
"Mengenalkan bahasa Inggris pada anak usia dini memerlukan kesabaran, ketelitian dan kemampuan mumpuni dari para guru. Anakanak di sekolah ini sudah dikenalkan dengan bahasa Inggris dengan materi dasar. Akan tetapi, hasil pembelajaran belum maksimal karena kemampuan guru terhadap penguasaan bahasa Inggris sangat terbatas. Hal ini dikarenakan latar belakang (background) pendidikan para guru tidak jurusan bahasa Inggris sehingga guru kurang semangat ketika mengajar bahasa inggris" (wawancara dengan Azizah, November 2018).

Selain itu, para guru juga harus memahami karakter dan emosi anak usia dini. Hal ini sesuai dengan pernyataan Dekker \& Wichgers (2018, hal. 65) bahwa emosi anak perlu dipertimbangkan oleh guru ketika mengajar karena anak-anak usia dini cenderung menunjukkan atau mengekspresikan perasaan atau emosinya seperti rasa senang, sedih, takut, marah, terkejut, ragu, dan sebagainya. Oleh karenanya, para guru sebaiknya mampu mengondisikan emosi anak terlebih dahulu dan memastikan mereka pada kondisi atau mood yang bagus.

\section{e. Anak-anak masih merasa kesulitan dalam mengucapkan kata dan kalimat bahasa Inggris.}

Bahasa Inggris bagi anak-anak usia dini di Indonesia terutama di Kudus merupakan bahasa asing sehingga mereka memerlukan waktu dalam belajar bahasa Inggris. Dalam kehidupan sehari-hari sebagian anak-anak usia dini di Kudus berinteraksi dengan lingkungan sekitar menggunakan bahasa Jawa, sedangkan sebagian lainnya menggunakan bahasa Indonesia. Lebih dari itu, mereka juga kurang mengenal budaya bahasa Inggris. Dengan demikian, hal ini menjadikan mereka merasa kesulitan dalam mempelajari bahasa Inggris terutama dalam pengucapan kata dan kalimat bahasa Inggris. Kesulitan yang dialami oleh anak dalam penguasaan bahasa sesuai dengan penelitian yang dilakukan oleh Brodin \& Renblad (2019, hal. 3) bahwa sebagian besar para guru pendidikan anak usia dini melaporkan bahwa anak-anak cenderung memiliki kendala dalam penguasaan bahasa dan ucapan dan mereka memerlukan dukungan dari para guru. Pentingnya peran guru dalam keberhasilan proses pembelajaran juga ditekankan oleh Klein \& Knitzer (2006, hal. 16) yang secara ekspilisit menjelaskan bahwa proses pembelajaran pada anak-anak usia dini dapat berhasil apabila guru dan anak dapat berinteraksi secara aktif, guru mampu menciptakan atmosfir pendidikan yang menarik, memberikan kesempatan pada anak untuk ikut terlibat secara aktif selama proses pembelajaran. 


\title{
f. Terbatasnya sarana penunjang dan fasilitas dalam pembelajaran bahasa Inggris
}

Sarana dan fasilitas merupakan salah satu aspek pendukung dalam proses pembelajaran. Anak-anak akan lebih mudah menerima materi apabila didukung dengan fasilitas dan sarana pembelajaran yang memadai. Sarana dan fasilitas dapat berupa tersedianya LCD di ruang kelas, ruangan kelas yang luas dan nyaman, rasio antara guru dan anak didik seimbang, buku-buku bahasa Inggris untuk anak usia dini, koleksi lagu-lagu anak bahasa Inggris yang menarik, film-film anak berbahasa Inggris dan sebagainya. Akan tetapi, sarana dan fasilitas yang mendukung dalam proses pembelajaran bahasa Inggris belum tentu dimiliki oleh kelompok bermain dan Taman Kanak-Kanak di Kudus. Hal ini sesuai dengan pernyataan Na’imah, mahasiswi jurusan PIAUD IAIN Kudus yang pernah praktik mengajar di Kelompok Bermain Taman Melati, Gebog Kudus :

\begin{abstract}
"Sarana dan fasilitas yang memadai merupakan aspekpenunjang dalam proses pembelajaran bagi anak-anak khususnya pembelajaran bahasa Inggris. Sekolah Kelompok Bermain ini belum memiliki LCD, koleksi buku-buku bahasa Inggris untuk anak masih sedikit, koleksi film bahasa Inggris tidak ada, rasio antara jumlah guru dan peserta didik belum seimbang sehingga guru merasa kewalahan ketika mengajar. Lebih dari itu, minimnya kemampuan dalam membuat kraetivitas dalam bahasa Inggris juga menjadi kendala dalam mengenalkan bahasa Inggris pada anak usia dini”. (wawancara dengan Na'imah, November 2018)
\end{abstract}

Berdasarkan penjelasan di atas, dapat dilihat bahwa pembelajaran bahasa Inggris akan berjalan lebih maksimal apabila didukung dengan fasilitas dan sarana yang memadai, rasio yang seimbang antara jumlah guru dengan jumlah anak didik dan kemampuan mengajar yang baik dari para guru. Adapun aturan rasio antara jumlah guru dan anak didik menurut permendikbud nomor 137 tahun 2014 yaitu untuk lembaga PAUD dengan anak didik usia 2-4 tahun rasionya guru dan anak maksimal 1:8. Untuk PAUD dengan anak didik berusia 4-6 tahun khususnya untuk jenjang Kelompok Bermain (KB) dan Taman Kanak-Kanak (TK), rasio guru dan anak maksimal 1: 15.

\section{g. Minimnya masukan (input) tentang bahasa Inggris dari lingkungan anak.}

Lingkungan merupakan salah satu faktor yang berpengaruh terhadap penguasaan bahasa yang dimiliki oleh anak. Hal ini sesuai dengan pernyataan Damar, Gursoy, \& Korkmaz (2013, hal. 106) yang menekankan bahwa masukan (input) dari keluarga, lingkungan dan sekolah tentang bahasa dalam hal ini bahasa Inggris seperti tersedianya kegiatan yang bersifat visual dan kinestetik 


\section{Sri Wahyuningsih}

bagi anak dan suasana atau lingkungan yang menyenangkan sangat penting bagi kemampuan anak terhadap penguasaan bahasa asing. Masukan (input) tentang bahasa Inggris dapat berupa kegiatan-kegiatan yang terpusat pada anak (child-centered activities) yang didukung dengan pengembangan secara holistik meliputi musik, tarian, cerita dan lagu-lagu sehingga dapat memberikan pengalaman natural kepada anak dan sikap positif terhadap bahasa asing.

Berdasarkan hasil observasi di beberapa Kelompok Bermain (KB) dan Taman Kanak-Kanak di Kudus, masukan (input) tentang bahasa Inggris dari keluarga, lingkungan dan sekolah bisa dikatakan terbatas. Latar belakang pendidikan orang tua siswa tidak bahasa Inggris. Orang tua dan anggota keluarga sering menggunakan bahasa Indonesia dan bahasa Jawa di rumah ketika melakukan interaksi. Selain itu, masyarakat di lingkungan sekitar anak lebih sering menggunakan bahasa Jawa ketika berinteraksi. Dengan demikian, dapat dilihat bahwa masukan (input) dari berbagai pihak berpengaruh terhadap pemerolehan bahasa anak.

\section{Simpulan}

Di era globalisasi, bahasa Inggris merupakan bahasa asing yang perlu dikuasai oleh masyarakat. Oleh karenanya, bahasa Inggris perlu diajarkan kepada anak didik di sekolah. Lebih lanjut, memperkenalkan bahasa Inggris kepada anak usia dini dirasa penting karena pada usia dini anak-anak akan lebih menyerap bahasa dengan mudah dan cepat. Salah satu media untuk memperkenalkan bahasa Inggris pada anak adalah melalui kreasi lagu anak berbahasa Inggris (nursery rhymes), yakni memodifikasi lagu anak bahasa Inggris dengan mengganti lirik yang disesuaikan dengan budaya dan kebutuhan atau tujuan materi. Keuntungan mengajarkan bahasa Inggris menggunakan kreasi lagu anak antara lain: melalui lagu anak, anak-anak merasa termotivasi ketika belajar bahasa Inggris. Dengan menyanyi, anak menjadi senang dan lebih mudah dalam memahami materi yang disampaikan guru. Meskipun demikian, ada beberapa kendala yang dihadapi ketika mengenalkan bahasa Inggris pada anak seperti terbatasnya daya perhatian dan konsentrasi anak terhadap guru ketika mengajar bahasa Inggris, beberapa anak masih menunjukkan rasa malu dan pasif ketika belajar bahasa Inggris, terbatasnya wawasan dan pengetahuan yang luas dari guru-guru di KB dan TK tentang pengajaran bahasa Inggris, anak-anak masih merasa kesulitan dalam mengucapkan kata dan kalimat bahasa Inggris, dan terbatasnya sarana penunjang dan fasilitas dalam pembelajaran bahasa Inggris. 


\section{Daftar Pustaka}

Brodin, J., \& Renblad, K. (2019). Improvement of preschool children's speech and language skills. Early Child Development and Care, o(o), 1-9. https://doi. org/10.1080/03004430.2018.1564917.

Damar, E., Gursoy, E., \& Korkmaz, S. (2013). Teaching English to Young Learners: Through the Eyes Teacher Trainer. ELT Reserach Journal, 2(3), 95-110.

Dekker, J. J. H., \& Wichgers, I. J. M. (2018). The embodiment of teaching the regulation of emotions in early modern europe. Paedagogica Historica, 54(1-2), 48-65. https://doi.org/10.1080/00309230.2017.1397713.

Ghanbari, F., \& Hashemian, M. (2014). The effects of English songs on young learners' listening comprehension \& pronunciation. International Journal of Language Learning and Applied Linguistics World, 6(3), 367-375.

Harper, L. J. (2011). Nursery Rhyme Knowledge and Phonological Awareness in Preschool Children. The Journal of Language and Literacy Education [Online], 7(1), 65-78.

Hery, I. S., Nair, S. M., \& Krishnasamy, H. N. (2016). Optimizing Nursery Rhymes to Promote Interests towards Learning English among Young Learners in Indonesia. Behavioural Science, 17(1), 1-14.

Klein, L., \& Knitzer, J. (2006). Effective Preschool Curricula and Teaching Strategies. Columbia: National Center for Children in Poverty.

Liakopoulou, M. (2011). 17.The Professional Competence of Teachers: Which qualities, attitudes, skills and knowledge contribute to a teacher' $\mathrm{s}$ effectiveness? International Journal of Humanities and Social Science, 1(21), 66-78.

Lonigan, C. J., Burgess, S. R., \& Anthony, J. L. (2000). Development of emergent literacy and early reading skills in preschool children: evidence from a latent-variable longitudinal study. Developmental Psychology, 36(5), $596-613$.

Mustafa, M. C., \& Ahmad, M. (2017). Effective Interaction Strategies In Teaching And Learning of English For Preschool Children. International Journal of Academic Research in Progressive Education and Development, 6(4), 13-40. https://doi.org/10.6007/IJARPED/v6-i4/3350. 
O' Connell, J. (2009). Preschool English Learners: Principles and Practices to Promote Language, Literacy, and Learning. California: California Department of Education Sacramento.

Parlakian, Rebecca, \& Lerner, C. (2010). Beyond Twinkle, Twinkle Using Music with Infants and Toddlers.

Pourkalhor, O., \& Tavakoli, M. A. (2017). Nursery Rhymes and Language Learning: Issues and Pedagogical Implications. International Journal of English Language \& Translation Studies, 5(1), 111-116.

Prosic-santovac, D. (2015). Making the Match : Traditional Nursery Rhymes and Teaching English to Modern Children. Children's Literature in English Language Education, 3(1), 25-48.

Taylor, et al. (2012). Music and Movement for Young Learners's Healthy Developmen. Dimensions of Early Childhood, 4O(2), 33-40.

Wahyuningsih, S. (2017). Lagu Anak Sebagai Media Dalam Mendidik Karakter Anak Usia Dini. Thufula, 5(1), 150-180. 
Kreasi Lagu Anak Berbahasa Inggris (Nursery Rhymes) ...

$\frac{\text { 岁 }}{206}$ 